\title{
Synthesis And Characterization of Nanoparticles $\mathrm{CaCO}_{3} / \mathrm{MgO}$ as Antibacterial
}

\author{
Zahrotul Jannah ${ }^{1}$, Lydia Rohmawati ${ }^{2}$, Woro Setyarsih ${ }^{3}$ \\ \{zjannah14@gmail.com ${ }^{1}$, lydiarohmawati@unesa.ac.id ${ }^{2}$,wsetyarsih@gmail.com ${ }^{3}$ \} \\ Department of physics, Faculty of Mathematics and Natural Science, Universitas Negeri Surabaya, \\ Surabaya, Indonesia ${ }^{1,2,3}$
}

\begin{abstract}
Nanoparticles $\mathrm{CaCO}_{3} / \mathrm{MgO}$ by variation percent weight of $\mathrm{MgO}(5,21,22,23$, 24 , and 25) wt.\% potentially antibacterial can be synthesized by mixing methods and calcination at temperature $800 \mathrm{oC}$, which synthesis $\mathrm{CaCO}_{3}$ from shellfish (Anadara granosa) using carbonation methods by flow velocity of $\mathrm{CO}_{2}$ gas 2.8 liters $/ \mathrm{min}$. The successful nanoparticles were characterized by BET, antibacterial activity and PSA. Variation percent weight of $\mathrm{MgO}$ was used to determine pore size, surface area and antibacterial activity on nanoparticles $\mathrm{CaCO}_{3} / \mathrm{MgO}$. The results showed that the weight percent variation of $\mathrm{MgO}$ has a different pore size and surface area that is included in the mesoporous category. $\mathrm{CaCO}_{3} / \mathrm{MgO}(5 \mathrm{wt} . \%)$ has the smallest surface area $(3.24 \mathrm{~m} 2 / \mathrm{g})$ and the largest pore size $(20.12-29.35 \mathrm{~nm})$, while $\mathrm{CaCO}_{3} / \mathrm{MgO}(24 \mathrm{wt} . \%)$ has the largest surface area $(65.05 \mathrm{~m} 2 / \mathrm{g})$ and the smallest pore size $(3.23-3.59 \mathrm{~nm})$ by the closed end of the curve.
\end{abstract}

Keywords: synthesis, characterization, nanoparticles, $\mathrm{CaCO}_{3} / \mathrm{MgO}$, antibacterial.

\section{Introduction}

Mouth and teeth are vital digestive organs. Early entry of food into the human body through these two organs, thus causing both are susceptible to the growth of pathogenic bacteria and viruses. One of the acute and chronic diseases that affect humans is the mouth disease caused by the growth of pathogenic bacteria [1]. There are more than 500 species of bacteria living in the oral cavity of humans [2]. All types of harmful bacteria living in the oral cavity can form plaque on the tooth surface and cause inflammation of the oral cavity [3]. One type of bacteria that can cause plaque on the teeth is Staphylococcus aureus bacteria [4]. Staphylococcus aureus bacteria is a pathogenic bacterium that lives in the oral cavity of humans and can cause various diseases such as necrosis, inflammation and abscess formation in the oral cavity [5]. In addition, other types of bacteria such as Escherichia coli can also cause dental plaque [6]. Both types of bacteria are commonly used as test bacteria in research on antibacterial or antibiotic.

However abrasive is not enough to remove bacteria because it has no antibacterial activity [7]. Therefore, it takes a material that has two functions such as abrasive tooth and has antibacterial properties. Antibacterial material consists of organic and inorganic materials. Inorganic materials such as $\mathrm{MgO}$, more in demand because it has good stability compared to organic materials [8]. $\mathrm{MgO}$ is one of the inorganic materials that have good antibacterial activity [9] and safe for humans [10]. To increase antibacterial activity in antibacterial materials, it takes a small particle size and large surface area so that the absorption of the bacteria is greater. This goal can be achieved by utilizing nanotechnology. Nanotechnology potentially changes the 
particle size to the nanoscale $(<100 \mathrm{~nm})$ in order to have a remarkable ability called nanomaterials [11].

$\mathrm{CaCO}_{3}$ and $\mathrm{MgO}$ are pore material that has the ability to adsorption so that it can damage the surface of bacteria causing bacterial growth activity is inhibited. Active oxygen groups such as superoxide anions $\mathrm{O}_{2}{ }^{-}$on the $\mathrm{CaCO}_{3} / \mathrm{MgO}$ surface as well as the alkaline effect that causes the rise in $\mathrm{pH}$ to be a major factor in the emergence of antibacterial activity [12]. The presence of antibacterial activity in the material is caused by the electrostatic interaction between the surface of the material and the surface of the bacteria [11]. By electrochemical work $\mathrm{MgO}$ penetrates and disrupts the bacterial cell wall, then leakage of metabolites resulting in other cell functions stop, thus preventing bacterial organisms to function or reproduce [13].

Antibacterial from $\mathrm{CaCO}_{3} / \mathrm{MgO}$ composite obtained from dolomite heating (carbonless) and dolomite-PVA (carbon coating) mixture showed the best antibacterial activity was obtained from carbonless with mesoporous category and surface area of 4,0 $\mathrm{m}^{2} \mathrm{~g}^{-1}$ [12]. Antibacterial material of the $\mathrm{CaCO}_{3} / \mathrm{MgO}$ composite nanoscale taken with dolomite heating at temperature $800{ }^{\circ} \mathrm{C}$ showed strong antibacterial activity on Staphylococcus aureus and Escherichia coli bacteria [7]. The study did not use percent weight variation because the composites were obtained by the in-situ method, with compositions already prepared in nature, ie dolomite heated to temperature $800{ }^{\circ} \mathrm{C}$. On the other hand, antibacterial $\mathrm{CaCO}_{3} / \mathrm{MgO}$ composite by weight percent $\mathrm{MgO}$ of $20 \mathrm{wt} . \%, 15 \mathrm{wt} . \%$, dan $10 \mathrm{wt} . \%$, yielded the greatest antibacterial activity on the composition of $20 \mathrm{wt} . \% \mathrm{MgO}$ and the smallest at $10 \mathrm{wt} \% \mathrm{MgO}$ [14].

Based on the description, this study was conducted to describe pore size and surface area and antibacterial activity of nanoparticles $\mathrm{CaCO}_{3} / \mathrm{MgO}$ using the ex-situ method where $\mathrm{CaCO}_{3}$ from shellfish. Difference in percent weight variation $\mathrm{CaCO}_{3} / \mathrm{MgO}$ by $95,79,78,77,76,75$ wt. $\% \mathrm{CaCO}_{3}$ dan 5, 21, 22, 23, 24, 25 wt.\% MgO, so from this research can be known addition of percent weight $\mathrm{CaCO}_{3} / \mathrm{MgO}$ which produces antibacterial agents with the most effective inhibitory zone.

\section{Experimental}

Materials used in this study are shellfish, $\mathrm{HCl} 12 \mathrm{M}(37 \%), \mathrm{NH}_{4} \mathrm{OH}(20 \%)$, distilled water, $\mathrm{CO}_{2}$, PEG 4000, $\mathrm{MgO}$ powder. According to [15] the preparation of calcium carbonate extract from the shellfish begins by washing the shells until clean and dried for a day then soaked by $\mathrm{HCl} 2 \mathrm{M}$ for 24 hours, washed again with distilled water then dried over for 24 hours, then the sample is smoothed using mortar and pestle, sieved with sieve 200 mesh size to obtain homogeneous particle size. After that, it is calcined at temperature $900{ }^{\circ} \mathrm{C}$ for 5 hours, then dissolved in $\mathrm{HCl} 10 \mathrm{M}$. After the solution is obtained $\mathrm{CaCl}_{2}$, samples added $\mathrm{NH}_{4} \mathrm{OH}$ to obtain $\mathrm{pH} 10$ and flowed by $\mathrm{CO}_{2}$ gas of 2.8 liters/min. Next, it is deposited for 36 hours, the precipitate is filtered and heated at a temperature of $90^{\circ} \mathrm{C}$.

The total mass of the sample used is 5 grams. The sample was then dissolved in a solution consisting of 6 grams of PEG 4000 and $20 \mathrm{ml}$ of distilled water by $7 \mathrm{rpm}$ at temperature $80 \mathrm{oC}$ for $30 \mathrm{~min}$. Samples were filtered using filter paper and heated at $90{ }^{\circ} \mathrm{C}$ for 3 hours. After that, the sample is smoothed and heated at $800^{\circ} \mathrm{C}$ for 30 minutes. Samples were taken at room temperature then smoothed to powder. The composite powder of $\mathrm{CaCO} / \mathrm{MgO}$ was characterized by BET to determine the pore size and surface area, test the antibacterial activity to determine the inhibitory zone and the PSA to know the particle size. 


\section{Result and Discussion}

\subsection{BET Characterization}

The surface area of the antibacterial material may affect the absorption of bacteria in the process of inhibition of antibacterial activity. The pore size category can be determined based on the adsorption-desorption curve in Figure 1 The adsorption-desorption curve was obtained from the BJH (Barret-Joyner-Hallenda) data based on the BET characterization.

According to Figure 1 the samples 5\%;21\%; 23\%; 24\% and 25\%, with 5wt.\% distribution of the largest adsorption pore size is $0.0003599481 \mathrm{cc} / \mathrm{nm} / \mathrm{g}$ at pore diameter $29.3518 \mathrm{~nm}$, while the largest desorption pore distribution is $0.0004365223 \mathrm{cc} / \mathrm{nm} / \mathrm{g}$ with pore diameter 20.1252 $\mathrm{nm}$, so the pore size of $5 \mathrm{wt} . \%$ is in the range of $20.12-29.35 \mathrm{~nm}$. Sample $21 \mathrm{wt} . \%$ has the largest adsorption pore size is $0.005314805 \mathrm{cc} / \mathrm{nm} / \mathrm{g}$ at a pore diameter of $3.3949 \mathrm{~nm}$, while the largest desorption pore distribution is $03375163 \mathrm{cc} / \mathrm{nm} / \mathrm{g}$ with a pore diameter of $3.2839 \mathrm{~nm}$, so that sample pore size $21 \mathrm{wt} . \%$ is in the range $3.28-3.39 \mathrm{~nm}$. Different results were also obtained in $25 \mathrm{wt}$.\% samples having the largest adsorption pore size of $0.006586851 \mathrm{cc} / \mathrm{nm} / \mathrm{g}$, while the largest desorption pore distribution was $0.02487782 \mathrm{cc} / \mathrm{nm} / \mathrm{g}$ with a sample pore size of $\mathrm{F}$ in the range 3.57-29.91 nm. Thus the pore size distribution in all samples showed the mesoporous category $(2 \mathrm{~nm}<\mathrm{d}<50 \mathrm{~nm})$.

The ability of antibacterial material to absorb bacteria can be known in the adsorptiondesorption process of nitrogen gas. If the BET absorbate test used is nitrogen gas, then in the antibacterial activity test that becomes absorbate is bacteria. In the absorption of bacteria required the right pore size so that bacteria can be absorbed and does not damage the host bacteria. If applied as an antibacterial to the teeth and oral cavity, too large pore size can damage the tooth because antibacterial pores can absorb bacteria as well as layers that protect teeth. Similarly, pore size is too small can't absorb bacteria with a larger size of the pore.

The adsorption-desorption data in this study is also supported by the isotherm graph in Figure 2 for all samples. The isotherm curve of all samples showed an isotherm form of type IV which is a characteristic of mesoporous material $(2 \mathrm{~nm}<\mathrm{d}<50 \mathrm{~nm}$ ) with H1 hysteresis loops showing cylindrical pore shape. Based on Figure 3 there are 3 prominent curves of curves in samples $5 \mathrm{wt} . \%, 21 \mathrm{wt} . \%$, and $24 \mathrm{wt} . \%$. The sample 5wt.\% curve lies at the bottom of the other curves indicating that sample 5wt.\% absorbs a small amount of nitrogen gas during the adsorption-desorption process, the $24 \mathrm{wt} . \%$ the sample is at the very top showing that sample 24 wt.\% absorbs much of the nitrogen gas. The shape of the sample curve B differs from the other curves with the open end curve. The open curve end indicates that the adsorbed nitrogen gas at the time of adsorption is retained within the pore so that the volume of the absorbed gas is greater than the volume of gas released during desorption. The three curve forms can be seen more clearly in Figure 3. 

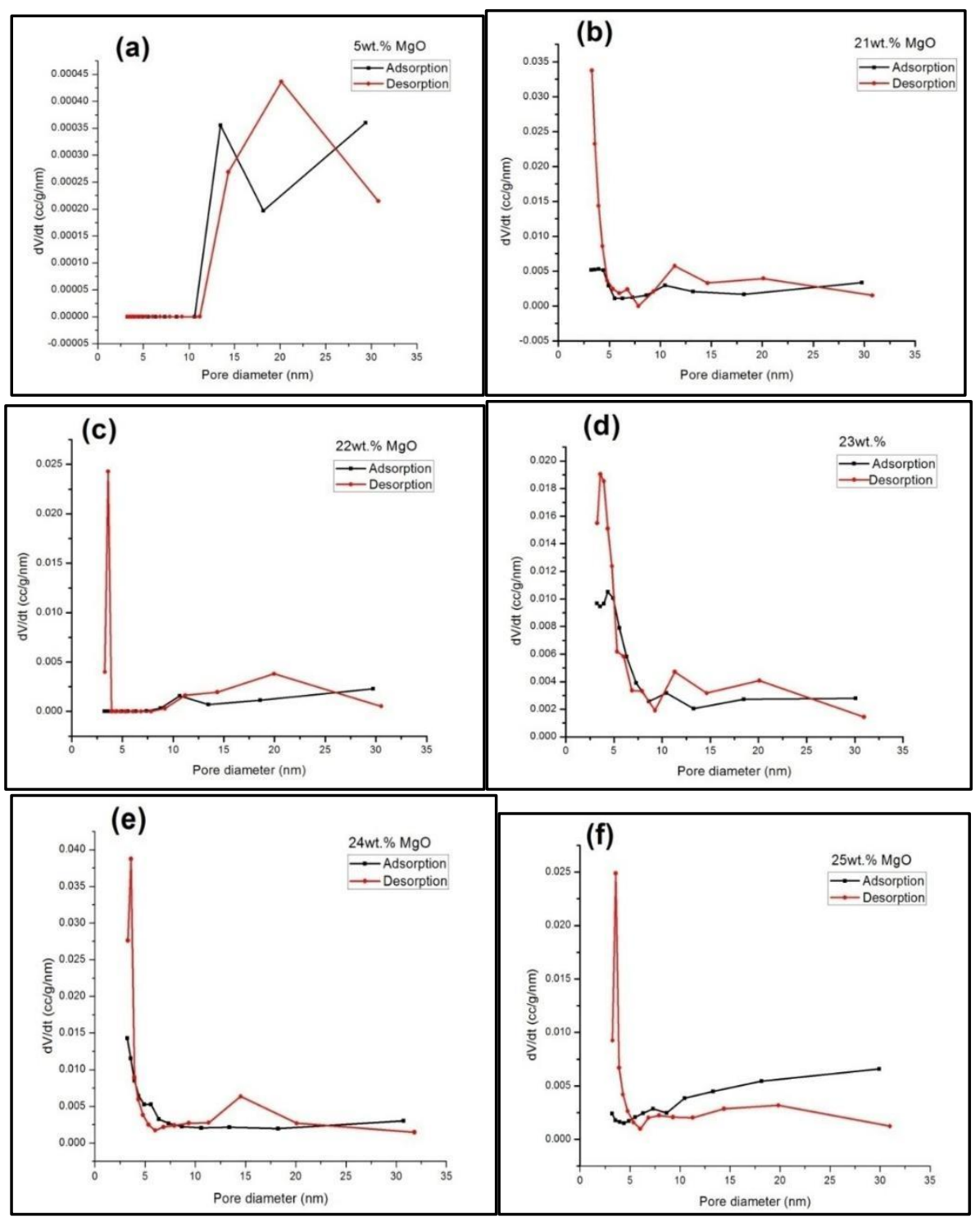

Fig. 1. Pore size distribution.

If applied to bacteria, then the bacteria are absorbed will be released again so that the antibacterial effectiveness is reduced. In contrast to the $24 \mathrm{wt}$. $\%$ with the open end, it gives a chance for bacteria to be trapped in the pore cavity resulting in better antibacterial effectiveness compared to other samples. To prove that the amount of nitrogen gas absorbed and released during the adsorption-desorption process in the sample is the same that the volume of nitrogen gas absorbed in the adsorption process is equal to the volume of gas released during desorption. The pore shape of $\mathrm{CaCO}_{3} / \mathrm{MgO}$ powder is different from that of $S$. aureus bacteria having rounded shape and E. coli where short stem shape [16]. To prove that the powder of 
$\mathrm{CaCO}_{3} / \mathrm{MgO}$ is antibacterial material, antibacterial activity test for $S$. aureus and $E$. coli bacteria is tested.

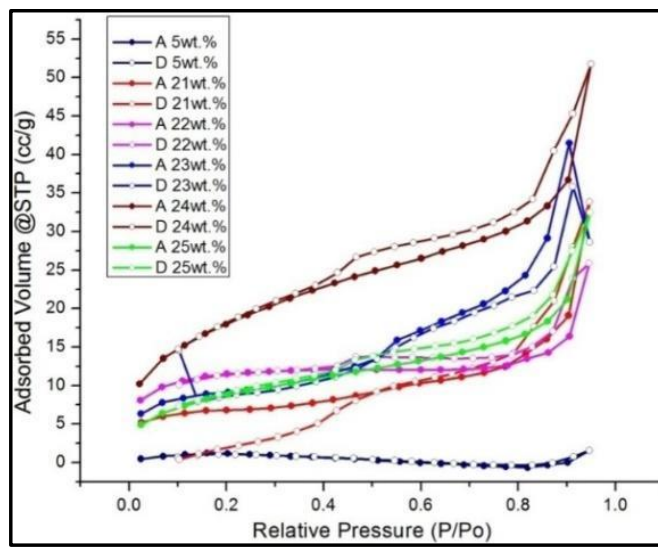

Fig. 2. Isotherm curve of $\mathrm{CaCO}_{3} / \mathrm{MgO}$.

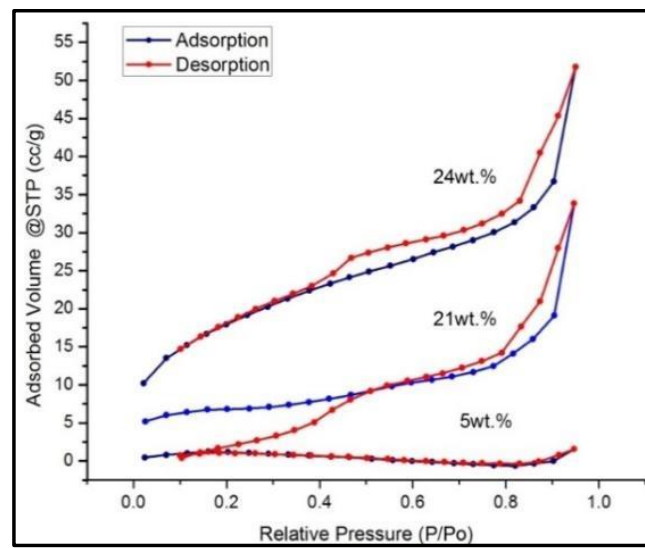

Fig. 3. adsorption-desorption isotherm curve of sample $5 \mathrm{wt} . \%, 21 \mathrm{wt} . \%$, and $24 \mathrm{wt} . \%$.

\subsection{Antibacterial Activity}

The antibacterial activity test was performed on $S$. aureus bacteria as Gram-positive bacteria and E. coli as Gram-negative bacteria. Antibacterial effectiveness is characterized by a clear zone around the paper disc that has been given antibacterial. The presence of a clear zone in the cup indicates that there is no bacterial growth in the area, whereas areas that no clear zone indicate that there is bacterial growth in the area. The resulting clear zone is then measured in horizontal and vertical diameter. The inhibition zone diameter obtained in Table 1.

Table 1. The inhibition zone diameter of materials.

\begin{tabular}{lll}
\hline \multirow{2}{*}{ Sample (wt.\%) } & \multicolumn{2}{l}{ The inhibition zone diameter $(\mathrm{mm})$} \\
& S. aureus & E. coli \\
\hline 5 & 14.0 & 11.0 \\
21 & 31.0 & 33.0 \\
22 & 31.0 & 20.5 \\
23 & 31.0 & 30.5 \\
24 & 21.5 & 20.5 \\
25 & 18.5 & 27.0 \\
\hline
\end{tabular}

The results of the antibacterial activity test showed that in this study obtained the value of clear zone diameter. The largest inhibitory zone diameter belongs to sample B with a composition of $79 \mathrm{wt} . \% \mathrm{CaCO}_{3}$ and $21 \mathrm{wt} . \% \mathrm{MgO}$ in E. coli bacteria, whereas in $S$. aureus bacteria the largest inhibitory diameter zone in samples $21 \mathrm{wt} . \%$, 22wt. $\%$ and $23 \mathrm{wt} . \%$. $\mathrm{CaCO}_{3} / \mathrm{MgO}$ is a porous material having the ability of adsorption so that it can damage the 
surface of bacteria causing bacterial metabolism inhibited. The adsorption ability is based on the surface area and pore size of the material. The samples in this study are known to have different surface areas and pore sizes that affect the antibacterial activity. In addition to porous, $\mathrm{CaCO}_{3} / \mathrm{MgO}$ is also class of alkali metal oxides, in which metal elements can raise bacterial $\mathrm{pH}$ and superoxide groups $\mathrm{O}_{2}{ }^{-}$can put pressure on the cell wall of bacteria and bind cell membranes that cause bacterial metabolism to stop [7-8]. Overall it can be seen that antibacterial materials from $\mathrm{CaCO}_{3} / \mathrm{MgO}$ nanoparticles tend to be more reactive to the types of gram-positive bacteria. This is due to differences in the shape and size of bacteria and the structure and chemical composition of bacterial cell walls in both types of bacteria [12]. This type of antibacterial material in this study can be classified as bacteriostatic, an antibacterial that has activity inhibiting bacterial growth (inhibiting the multiplication of bacterial population) [17] but did not kill the bacteria as a whole, as evidenced by the clear zone formed relatively small compared to the diameter of the cup. In addition to the above-mentioned factors, other factors affecting the inhibitory activity of antibacterial agents are the size of particles possessed by antibacterial materials. Some antibacterial materials that have good antibacterial activity are materials in nano size, such as $\mathrm{MgO}, \mathrm{TiO}_{2}$ and $\mathrm{ZnO}$. To investigate the particle size held by the $\mathrm{CaCO}_{3} / \mathrm{MgO}$ composite, PSA (Particle Size Analyzer) characterization was performed on the sample with the largest inhibitory zone diameter.

\subsection{PSA Characterization}

The PSA (Particle Size Analyzer) test aims to determine the particle size of the $\mathrm{CaCO}_{3} / \mathrm{MgO}$ composite as an antibacterial material. The particle size of antibacterial material is very influential on the inhibitory activity of bacteria. According to[13] the power of antibacterial increases with decreasing particle size. This is due to the larger surface area as the particle size decreases. The sample used in the PSA test was sample B with a composition of $79 \mathrm{wt} . \% \mathrm{CaCO}_{3}$ and $21 \mathrm{wt} . \% \mathrm{MgO}$. The tested sample was based on antibacterial activity test results with the largest inhibitory zone in this study. The powder tested has different particle sizes with different intensities as shown in Figure 4.

Figure 4 shows the smallest particle size in sample B is $105.7 \mathrm{~nm}$ with an intensity of $0.9 \%$ while the largest patent size is $1.718 \mathrm{~nm}$ with an intensity of $0.2 \%$. The greatest intensity occurred at $164.2 \mathrm{~nm}$ particle size with $24.7 \%$ intensity. From these results, it is known that the particle size in the sample is still too large that is $>100 \mathrm{~nm}$. Generally, the material can be called nano if it has dimensions between $1-100 \mathrm{~nm}$, but taking into account factors that may affect particle size changes such as dispersion, ultrafiltration, as well as calcination, the use of nanoscale prefixes is acceptable by dimensions $<500 \mathrm{~nm}$. Thus, the antibacterial material successfully made in this study can be referred to as $\mathrm{CaCO}_{3} / \mathrm{MgO}$ nanoparticles. When compared, $\mathrm{MgO}$ of smaller size has a smaller inhibitory power than larger-sized $\mathrm{CaCO}_{3} / \mathrm{MgO}$ powder, because the $\mathrm{CaCO}_{3} / \mathrm{MgO}$ powder has more metal ions than $\mathrm{MgO}$. 


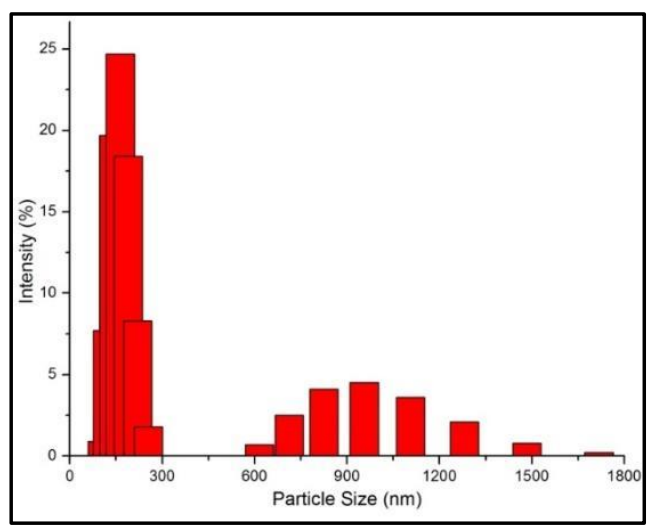

Fig. 4. Particle size distribution of sample $\mathrm{CaCO}_{3} / 21 \mathrm{wt} . \% \mathrm{MgO}$.

\section{Conclusion}

The weight percentage of $\mathrm{MgO}$ in $\mathrm{CaCO}_{3} / \mathrm{MgO}$ nanoparticles $(5,21,22,23,24$, and 25) wt.\% Yields different pore sizes and surface areas under the mesoporous category $(2<\mathrm{d}<50$ $\mathrm{nm})$. The sample $5 \mathrm{wt} . \%$ has the smallest surface area $\left(3.24 \mathrm{~m}^{2} / \mathrm{g}\right)$ and the largest pore size $(20.12-29.35 \mathrm{~nm})$, while the sample $24 \mathrm{wt} . \%$ has the largest surface area $\left(65.05 \mathrm{~m}^{2} / \mathrm{g}\right)$ and the smallest pore size (3.23-3.59 nm). Nanoparticles with a percent weight percentage of $\mathrm{MgO}$ have different antibacterial activity in Staphylococcus aureus and Escherichia coli bacteria. The largest inhibitory zone is owned by $21 \mathrm{wt} . \% \mathrm{MgO}$ with a diameter of $33.0 \mathrm{~mm}$ inhibition zone in Escherichia coli bacteria, whereas in S. aureus the largest inhibitory zone is $31.0 \mathrm{~mm}$ which occurs in $21 \mathrm{wt} . \%, 22 \mathrm{wt} . \%$, and $23 \mathrm{wt} . \%$. Nanoparticles with the greatest clear zone have particle size $<200 \mathrm{~nm}$.

Acknowledgments. We wish to thank Kemenristek DIKTI for financial support for our project in the Fundamental Research 2017.

\section{References}

[1] Senpuku, H., Sogame, A., Inoshita, E., Tsuha, Y., Miyazaki, H. and Hanada, N.: Systemic Diseases in Association with Microbial Species in Oral Biofilm from Elderly Recuiring Care, Gerontology, vol. 49, pp. 301-309 (2003)

[2] Kroes, I., Lepp, P. W., and Relman, D. A.: Bacterial diversity within the human subgingival crevice. Proc. Natl. Acad. Sci. U. S. A., vol. 96, no. 25, pp. 14547-52 (1999)

[3] Okuda, K. and Ebiraha, Y.: Relationships between chronic oral infectious diseases and systemic diseases. Bull Tokyo Dent Coll., vol. 39, no. 3, pp. 165-74 (1998)

[4] Tada, A., Senpuku, H., Motozawa, Y., Yoshihara, A., Hanada, N., and Tanzawa, H.: Association between commensal bacteria and opportunistic pathogens in the dental plaque of elderly individuals. Clin. Microbiol. Infect., vol. 12, no. 8, pp. 776-781 (2006) 
[5] Merghni, A., Nejma, M. B., Hentati, H., Mahjoub, A., \& Mastouri, M.: Adhesive properties and extracellular enzymatic activity of Staphylococcus aureus strains isolated from oral cavity. Microbial pathogenesis, 73, 7-12 (2014)

[6] Islam, M. R., Ogura, Y., Asadulghani, M., Ooka, T., Murase, K., Gotoh, Y., \& Hayashi, T.: A sensitive and simple plaque formation method for the Stx2 phage of Escherichia coli O157: H7, which does not form plaques in the standard plating procedure. Plasmid, 67(3), 227-235 (2012)

[7] Yamamoto, O., Ohira, T., Alvarez, K., \& Fukuda, M.: Antibacterial characteristics of CaCO3MgO composites. Materials Science and Engineering: B, 173(1-3), 208-212 (2010)

[8] Hewitt, C. J., Bellara, S. R., Andreani, A., Nebe-von-Caron, G., \& McFarlane, C. M.: An evaluation of the anti-bacterial action of ceramic powder slurries using multi-parameter flow cytometry. Biotechnology letters, 23(9), 667-675 (2001)

[9] Tang, Z. X., \& Lv, B. F.: MgO nanoparticles as antibacterial agent: preparation and activity. Brazilian Journal of Chemical Engineering, 31(3), 591-601 (2014)

[10] Stoimenov, P. K., Klinger, R. L., Marchin, G. L., \& Klabunde, K. J.: Metal oxide nanoparticles as bactericidal agents. Langmuir, 18(17), 6679-6686 (2002)

[11] Munasir, M., Triwikantoro, T., Zainuri, M., \& Darminto, D.: Uji XRD dan XRF Pada Bahan Meneral (Batuan dan Pasir) Sebagai Sumber Material Cerdas (CaCO3 DAN SiO2). Jurnal Penelitian Fisika dan Aplikasinya (JPFA), 2(1), 20-29 (2012)

[12] Yamamoto, O., Ohira, T., Mohan, D. J., Fukuda, M., Özkal, B., Sawai, J., \& Nakagawa, Z. E.: Antibacterial characteristics of carboncoated $\mathrm{CaCO} / \mathrm{Mg} 0$ powder led by the pyrolysis of poly (vinyl alcohol)-dolomite mixture. TANSO, 2008(232), 77-81 (2008)

[13] Sundrarajan, M., Suresh, J., \& Gandhi, R. R.: A comparative study on antibacterial properties of $\mathrm{MgO}$ nanoparticles prepared under different calcination temperature. Digest journal of nanomaterials and biostructures, 7(3), 983-989 (2012)

[14] Jannah, Z., Mubarok, H., Syamsiyah, F., Putri, A. H., \& Rohmawati, L.: Preparation of Calcium Carbonate (from Shellfish)/Magnesium Oxide Composites as an Antibacterial Agent. In IOP Conference Series: Materials Science and Engineering (Vol. 367, No. 1, p. 012005) (2018)

[15] Nurjanah, I., Putri, N. P., \& Rohmawati, L.: Pengaruh Variasi Kecepatan Aliran Gas CO2 Terhadap Kemurnian dan Ukuran Kristal Nanokalsit dari Cangkang Kerang Bulu dengan Metode Karbonasi. Inovasi Fisika Indonesia, 2(03) (2013)

[16] Raho, G. B., \& Abouni, B.: Escherichia coli and Staphylococcus aureus most common source of infection. The Battle against Microbial Pathogens: Basic Science, Technological Advances and Educational Programs; Méndez-Vilas, A., Ed (2015)

[17] Pankey, G. A., \& Sabath, L. D.: Clinical relevance of bacteriostatic versus bactericidal mechanisms of action in the treatment of Gram-positive bacterial infections. Clinical infectious diseases, 38(6), 864870 (2004) 